\title{
Pelodictyon phaeoclathratiforme sp. nov., a new brown-colored member of the Chlorobiaceae forming net-like colonies
}

\author{
Jörg Overmann and Norbert Pfennig \\ Fakultät für Biologie, Universität Konstanz, D-7750 Konstanz, Federal Republic of Germany
}

\begin{abstract}
A new strain of the green sulfur bacteria was isolated from the monimolimnion of Buchensee (near Radolfzell, Lake Constance region, FRG). Single cells were rod-shaped, nonmotile and contained gas vacuoles. Typical net-like colonies were formed by ternary fission of the cells. As photosynthetic pigments bacteriochlorophylls $a, e$, isorenieratene and $\beta$-isorenieratene were present. Sulfide, sulfur and thiosulfate were used as electron donors during anaerobic phototrophic growth. Besides carbon dioxide, acetate and propionate could serve as carbon sources under mixotrophic conditions in the light. Like all other members of the green sulfur bacteria, the new bacterium is strictly anaerobic and obligately phototrophic. The possession of gas vacuoles and the formation of net-like colonies and the guanine plus cytosine content of the DNA $(47.9 \mathrm{~mol} \%$ $\mathrm{G}+\mathrm{C}$ ) are typical characteristics of the genus Pelodictyon. Because of its photosynthetic pigments which differ from those of Pelodictyon clathratiforme, strain BU 1 represents a new species, $P$. phaeoclathratiforme sp. nov.
\end{abstract}

Key words: Chlorobiaceae - Pelodictyon - Net-like colonies - Gas vacuoles - Isorenieratene

In almost all genera of the green sulfur bacteria, pairs of brown- and green-colored species were described, which are morphologically, cytologically and physiologically similar. In contrast to the green species, their brown counterparts contain bacteriochlorophyll $e$ and the carotenoids isorenieratene and $\beta$-isorenieratene as major photosynthetic pigments.

Since the first description of the green-colored Pelodictyon clathratiforme by Lauterborn (1913), and its first cultivation and fine structure study by Pfennig and Cohen-Bazire (1967), two other species of this genus were described: the yellowish green $P$. luteolum (Pfennig and Trüper 1971a; Bergey's Manual 1974) and the brown-colored P. phaeum (Gorlenko 1972).

Pfennig (1977) isolated in pure culture a brown counterpart to the green Pelodictyon clathratiforme; unfortunately, it was lost before the strain was characterized in detail. Only recently, the isolation of a brown-colored Pelodictyon "phaeoglomerans" forming branched microcolonies was re-

Offprint requests to: J. Overmann ported (Abella and Montesinos 1985; Abella and GarciaGil 1988). However, only few experiments were conducted and no detailed description of this organism is available.

During studies of a meromictic kettle lake in the southern part of West-Germany, a mass development of the new brown Pelodictyon sp. was observed and one strain (BU 1) isolated in pure culture. The morphological and physiological properties of this new member of the genus Pelodictyon are described below.

\section{Materials and methods}

Source of organisms

Mittlerer Buchensee is a small meromictic kettle lake (surface area $11.8 \cdot 10^{3} \mathrm{~m}^{2}$, maximum depth $11.5 \mathrm{~m}$ ) exhibiting low phytoplankton productivity. It is located near Radolfzell in the Lake Constance region (FRG). Conspicuous accumulation of brown-colored bacterial cells morphologically resembling Pelodictyon clathratiforme occurred in the monimolimnion during summer and autumn of the five years studied.

\section{Isolation and cultivation}

Samples from the colored water layer at $9 \mathrm{~m}$ depth were stored at $+4{ }^{\circ} \mathrm{C}$ overnight. During this time, most of the suspended cell material had settled and could be used as inoculum. Pure cultures were obtained by repeated deep agar dilution series (Pfennig 1978) using an agar concentration of $1 \%$. To maintain reduced conditions, sterile $\mathrm{Na}_{2} \mathrm{~S}_{2} \mathrm{O}_{4}$ solution was added to a final concentration of $200 \mu \mathrm{M}$. The basal medium used for isolation and further cultivation of the organisms contained per liter distilled water: $\mathrm{KH}_{2} \mathrm{PO}_{4}$, $0.34 \mathrm{~g} ; \mathrm{NH}_{4} \mathrm{Cl}, 0.34 \mathrm{~g} ; \mathrm{KCl}, 0.34 \mathrm{~g} ; \mathrm{MgSO}_{4} \cdot 7 \mathrm{H}_{2} \mathrm{O}, 0.50 \mathrm{~g}$; $\mathrm{CaCl}_{2} \cdot 2 \mathrm{H}_{2} \mathrm{O}, 0.30 \mathrm{~g} ; \mathrm{NaHCO}_{3}, 1.50 \mathrm{~g} ; \mathrm{Na}_{2} \mathrm{~S} \cdot 9 \mathrm{H}_{2} \mathrm{O}$, $0.60 \mathrm{~g}$; vitamine $\mathrm{B}_{12}, 0.02 \mathrm{mg}$; trace element solution SL 10 (Widdel et al. 1983), $1 \mathrm{ml}$. The $\mathrm{pH}$ was adjusted to 6.7 to 6.8. The medium was sterilized and aseptically distributed into culture vessels as described by Pfennig and Trüper (1981).

Purity of the cultures was checked microscopically and by growth tests either in Difco AC medium or in basal medium supplemented with sterile glucose and glutamate solutions (concentration $5 \mathrm{mM}$, each).

Cultures were grown phototrophically in $50 \mathrm{ml}$ screw cap bottles at 200 lux (about $90 \mu \mathrm{E} \cdot \mathrm{m}^{-2} \cdot \mathrm{s}^{-1}$ ) light intensity 
of a tungsten lamp and a temperature of $20^{\circ} \mathrm{C}$ (standard conditions). Repeated addition of neutralized sulfide solution (Siefert and Pfennig 1984) resulted in higher cell yields. Stock cultures were stored at $4^{\circ} \mathrm{C}$ in the dark.

Growth experiments were performed in $22 \mathrm{ml}$ screw cap tubes. Growth was followed by measuring optical density at $650 \mathrm{~nm}$ (Bausch \& Lomb Spectronic 70 photometer) or following the increase of cell numbers in $250 \mathrm{ml}$ screw cap bottles using the DAPI technique (Porter and Feig 1980; filter: Nuclepore, $0.2 \mu \mathrm{m}$, stained with sudan-black) and an epifluorescence microscope. The last method had to be applied if sulfide was used as electron donor. Under these conditions, light scattering caused by sulfur globules interfered with the determination of growth by optical density readings.

The stoichiometry of growth with different substrates was determined in $250 \mathrm{ml} \mathrm{screw}$ cap bottles $\left(200\right.$ lux, $\left.20^{\circ} \mathrm{C}\right)$.

\section{Analytical procedures}

Absorption spectra were recorded with a Shimadzu UV 300 spectrophotometer equipped with an end-on photomultiplier. As ultrasonic treatment of cell suspensions did not result in sufficient decrease of light scattering, absorption spectra were recorded after passing the cells through a French press (Aminco, Silver Spring, MD, USA; pressure = $6.7 \cdot 10^{6} \mathrm{~Pa}$ ). Changes in the position of absorption maxima as compared to untreated samples were not observed.

Bacteriochlorophylls were extracted overnight at $4^{\circ} \mathrm{C}$ with acetone $(99.5 \%)$. Carotenoids were identified by thinlayer cochromatography as described by Eichler and Pfennig (1986). For comparison, Chlorobium phaeovibrioides strain 2531 and $C$. phaeobacteroides strain 2430 were used. Dry cell mass was calculated from optical density of $S^{\circ}$-free cells applying a conversion factor of $308 \mathrm{mg}$ dry cell mass per liter with $\mathrm{OD}_{650}=1.0$. This factor was obtained by direct yield determinations using $250 \mathrm{ml}$ cultures with thiosulfate and acetate.

Hydrogen sulfide was determined by the methylene blue method (Cline 1969). Sulfate and thiosulfate were measured by ion chromatography using a Sykam $\mathrm{S} 1000$ conductivity detector and a Shimadzu C-R3A integrator. Acetate was measured by gas chromatography (Schink and Pfennig 1982).

The $\mathrm{mol} \%$ guanine plus cytosine of the DNA was determined by Dr. Floßdorf, Braunschweig, according to Floßdorf (1983).

\section{Results \\ Isolation}

Only after application of $\mathrm{Na}_{2} \mathrm{~S}_{2} \mathrm{O}_{4}$ as reducing agent in addition to sulfide, the brown lense-shaped colonies of Pelodictyon sp. were obtained in the higher dilution steps of the deep agar tubes. Even then, colonies failed to develop in the upper first $\mathrm{cm}$ of the agar, indicating strong sensitivity to less reducing conditions.

\section{Morphology}

Individual cells of the isolated strain BU 1 were nonmotile, rod-shaped, and formed chains of different length. Usually, some of the cells were wider at one end and thus were
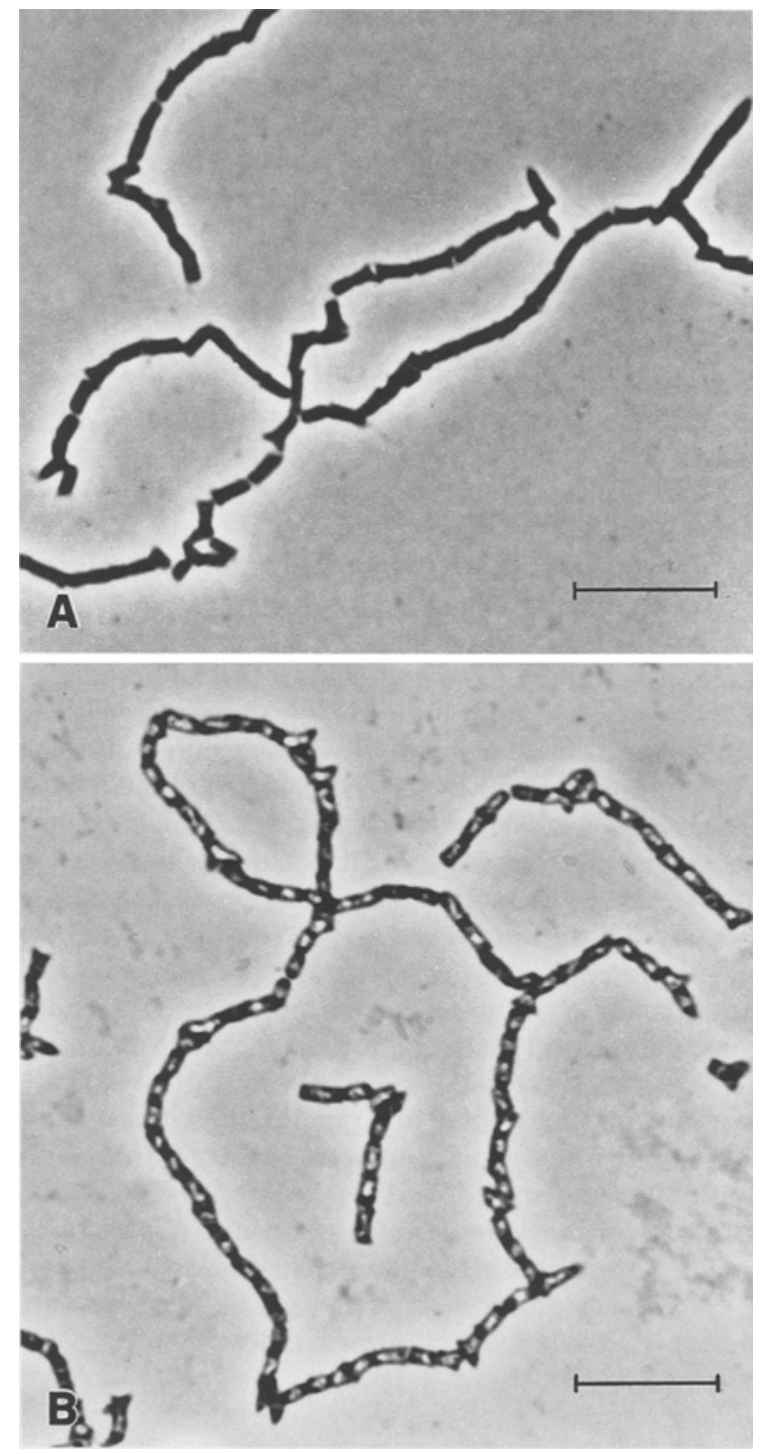

Fig. 1 A, B. Phase contrast photomicrograph of Pelodictyon strain BU 1. A Cells grown at 200 lux, $20^{\circ} \mathrm{C}$. B Ring-shaped colony grown at $40 \mathrm{lux}, 20^{\circ} \mathrm{C}$. Bar $=10 \mu \mathrm{m}$

trapezoid in shape. By ternary fission, these cells developed into $\mathrm{Y}$-shaped cells, leading to the formation of ring-shaped and branched colonies (Pfennig and Cohen-Bazire 1967) (Fig. 1). This was most common at light intensities below 60 lux.

Cells stained Gram-negative and were usually $1.5-3 \mu \mathrm{m}$ long and $0.75-1.1 \mu \mathrm{m}$ wide. Microscopical examination of cultures grown at various temperatures revealed significant differences with respect to cell length. While cells grown at $5^{\circ}$ and $10^{\circ} \mathrm{C}$ were $3.7 \mu \mathrm{m}$ (S. D. $\pm 0.8 \mu \mathrm{m}, n=20$ ) and $4.4 \mu \mathrm{m}$ $( \pm 1.1 \mu \mathrm{m}, n=20)$ long, those grown at higher temperatures were considerably shorter (at $15^{\circ} \mathrm{C}: 2.9 \pm 0.5 \mu \mathrm{m}$; at $25^{\circ} \mathrm{C}$ : $2.5 \pm 0.6 \mu \mathrm{m} ; n=10$ ). Cell length ranged between 1.5 and $6 \mu \mathrm{m}(n=110)$ over the whole temperature range examined. Only slight variation of cell width was observed $(0.75-$ $1.5 \mu \mathrm{m}$ over the whole temperature range, $n=110$ ). These results were obtained both in sulfide- and thiosulfate-containing media. By contrast, differences in cell size were less conspicuous in cultures grown at various light intensities but constant temperature. 


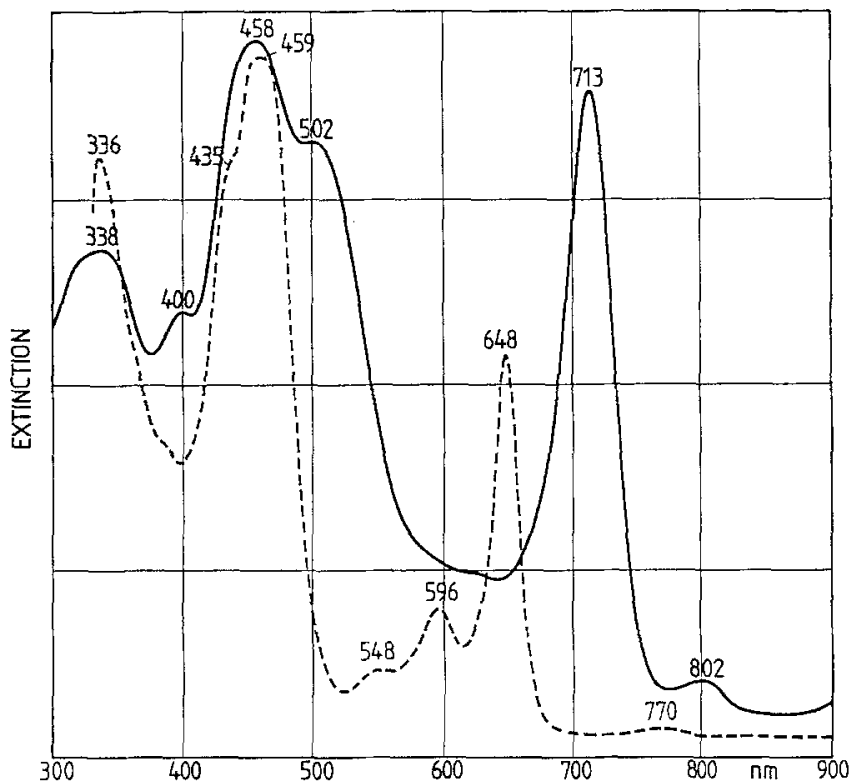

Fig. 2. Pelodictyon strain BU 1 absorption spectra, of whole cells $(-)$ and of acetone extract (--)

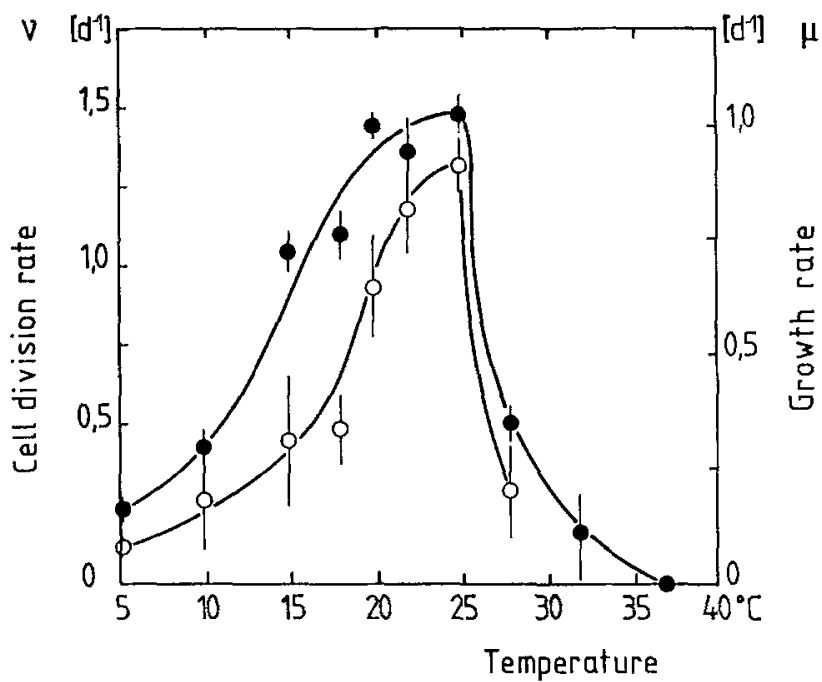

Fig. 3. Temperature dependence of growth rate $\mu$ and division rate $v$ of Pelodictyon strain BU 1. Closed circles $=$ growth with sulfide, open circles $=$ growth with thiosulfate as electron donor. Vertical bars represent standard deviations

In pure cultures usually no gas vacuoles were observed (Fig. 1 a). Under the same conditions in densely grown enrichment cultures, cells contained gas vacuoles. As selfshading in these dense cultures was high, the morphology of cells in pure cultures at different light intensities was examined. When growing at light intensities of a tungsten lamp lower than $60 \mathrm{lux}$ (about $30 \mu \mathrm{E} \cdot \mathrm{m}^{-2} \cdot \mathrm{s}^{-1}$ ) most cells contained gas vacuoles (Fig. 1 b). Low temperatures $\left(\leq 15^{\circ} \mathrm{C}\right)$ did not cause this pronounced effect.

During phototrophic growth with sulfide, globules of elemental sulfur appeared outside the cells.

The DNA base composition was $47.9 \mathrm{~mol} \%(\mathrm{G}+\mathrm{C})$.

\section{Photosynthetic pigments}

Densely grown cultures were of brown color. The in vivo absorption spectrum revealed maxima at $802,713,502,458$, 400 and $338 \mathrm{~nm}$ (Fig. 2). The minor absorption peak at $802 \mathrm{~nm}$ can be attributed to the presence of small amounts of bacteriochlorophyll $a$, the maxima at 713,458 and $338 \mathrm{~nm}$ are due to bacteriochlorophyll $e$, which differs from bacteriochlorophyll $c$ and $d$ in the position of the long wavelength absorption maximum in acetone extracts (646$648 \mathrm{~nm}$, Gloe et al. 1975; see Fig. 2). The shoulder at $502 \mathrm{~nm}$ is due to light absorption by the carotenoids isorenieratene and $\beta$-isorenieratene. Both pigments were identified as major carotenoids of the new Pelodictyon strain BU 1.

\section{Physiological properties}

Photolithoautotrophic growth occurred under strictly anoxic conditions with hydrogen sulfide, elemental sulfur, and thiosulfate as electron donors, but not with $\mathrm{H}_{2}$. Growth was significantly retarded at sulfide concentrations higher than $3 \mathrm{mM}$, and completely inhibited above $6 \mathrm{mM}$ sulfide. If sulfide-grown cells were transferred to medium with thiosulfate as electron donor, a lag phase of $48 \mathrm{~h}$ was observed. This indicates that utilization of thiosulfate is not constitutive in Pelodictyon strain BU 1. In the presence of reduced sulfur compounds and hydrogencarbonate, acetate and propionate were photoassimilated while pyruvate (final concentration $5 \mathrm{mM}$ ) and lactate $(10 \mathrm{mM})$ slightly inhibited growth. No growth was observed with even very low $(0.2 \mathrm{mM})$ concentrations of crotonate. Other substrates tested but not utilized were (concentrations in $\mathrm{mM}$ ): glucose (5), fructose (5), mannitol (5), gluconate (5), L(+)-ascorbate (5), methanol (5), ethanol (5), propanol (5), butanol (5), ethylenglycol (5), 1,2-propandiol (5), 1,2-butandiol (5), 2,3butandiol (5), glycerol (5), formate (2.5), butyrate (2.5), valerate $(0.5)$, caproate $(0.5)$, caprylate $(0.5)$, malonate $(5)$, succinate (10), fumarate (5), malate (5), tartrate (2), glycollate (5), 2-oxoglutarate (5), citrate (2), acetoin (10), benzoate (2), trimethoxybenzoate (2), L(+)-arginine (5), L(+)-glutamate $(5)$, peptone $(0.025 \%)$, casaminoacids $(0.1 \%)$, and yeast extract $(0.005 \%)$.

In the light, neither nitrate nor dinitrogen were used as nitrogen sources. No growth was obtained under anoxic conditions in the dark with nitrate as electron acceptor (final concentration 1 and $2 \mathrm{mM}$ ) indicating lack of dissimilatory nitrate reduction.

With sulfide as electron donor growth of Pelodictyon strain $\mathrm{BU} 1$ became light-saturated above light intensities of 200 lux (tungsten light, $92 \mu \mathrm{E} \cdot \mathrm{m}^{-2} \cdot \mathrm{s}^{-1}$ ). A maximum growth rate of $0.045 \mathrm{~h}^{-1}$ was obtained. Figure 3 shows the temperature dependence of growth rates at light saturation with hydrogen sulfide or thiosulfate as electron donor. The growth rates were maximal between $20^{\circ}$ and $25^{\circ} \mathrm{C}\left(\mu_{\max }=\right.$ $0.043 \mathrm{~h}^{-1}$ ) and decreased rapidly at higher temperatures.

The $\mathrm{pH}$ optimum of growth of strain $\mathrm{BU} 1$ was at $\mathrm{pH}$ 6.6. At increasing concentrations of $\mathrm{NaCl}$ up to $68 \mathrm{mM}$, a rapid decline of the growth rate was observed. At $86 \mathrm{mM}(0.5 \%)$ $\mathrm{NaCl}$ no growth occurred.

Strain BU 1 required vitamin $B_{12}$ for growth.

Figures 4 and 5 show thiosulfate-dependent growth under autotrophic and mixotrophic conditions with acetate.

Under autotrophic conditions biomass formation can be described by the following equation: 

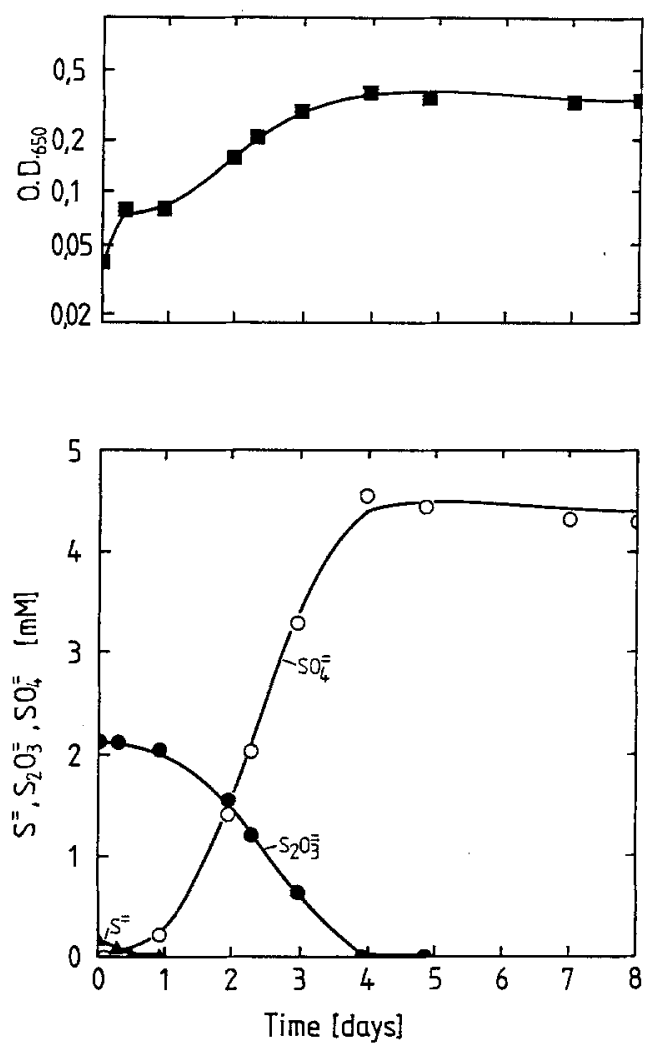

Fig. 4. Photoautotrophic growth of strain BU 1 on thiosulfate. Upper panel: Time course of optical density measured at $650 \mathrm{~nm}$. Lower panel: Time course of sulfide, thiosulfate, and sulfate concentrations

$17 \mathrm{H}_{2} \mathrm{~S}_{2} \mathrm{O}_{3}+37 \mathrm{H}_{2} \mathrm{O}+32 \mathrm{CO}_{2}+8 \mathrm{NH}_{3}$ $\rightarrow 34 \mathrm{H}_{2} \mathrm{SO}_{4}+8\left\langle\mathrm{C}_{4} \mathrm{H}_{8} \mathrm{O}_{2} \mathrm{~N}\right\rangle$

$2 \mathrm{mmol}$ thiosulfate $\rightarrow 96 \mathrm{mg}$ dry cell mass.

Experimentally, $2.12 \mathrm{mmol}$ thiosulfate and $0.17 \mathrm{mmol}$ sulfide (the last was added as a reductant) were consumed and $4.55 \mathrm{mmol}$ sulfate and $110 \mathrm{mg}$ dry cell mass were formed ( $93 \%$ of the theoretical yield).

Under mixotrophic growth conditions, biomass formation with thiosulfate, hydrogencarbonate and acetate can be described by the equation:

$17 \mathrm{H}_{2} \mathrm{~S}_{2} \mathrm{O}_{3}+9 \mathrm{H}_{2} \mathrm{O}+34 \mathrm{CH}_{3} \mathrm{COOH}+28 \mathrm{CO}_{2}+24 \mathrm{NH}_{3}$ $\rightarrow 34 \mathrm{H}_{2} \mathrm{SO}_{4}+24\left\langle\mathrm{C}_{4} \mathrm{H}_{8} \mathrm{O}_{2} \mathrm{~N}\right\rangle$

$2 \mathrm{mmol}$ thiosulfate $+4 \mathrm{mmol}$ acetate $\rightarrow 288 \mathrm{mg}$ dry cell mass.

Experimentally, $2.10 \mathrm{mmol}$ thiosulfate, $0.15 \mathrm{mmol}$ sulfide, and $4.00 \mathrm{mmol}$ acetate were consumed and $4.31 \mathrm{mmol}$ sulfate and $298 \mathrm{mg}$ dry cell mass were formed $(88 \%$ of the theoretical yield). The doubling time during autotrophic growth $\left(t_{\mathrm{d}}=24.7 \mathrm{~h}\right)$ was very similar to that during mixotrophic growth $\left(t_{\mathrm{d}}=23.8 \mathrm{~h}\right)$.

\section{Discussion}

The newly isolated bacterium is obligately phototrophic and grows only under strictly anaerobic and reducing conditions. It contains bacteriochlorophyll $e$ and the carotenoids isorenieratene and $\beta$-isorenieratene as major photosynthetic pigments. Therefore the isolate represents a member of the family Chlorobiaceae.
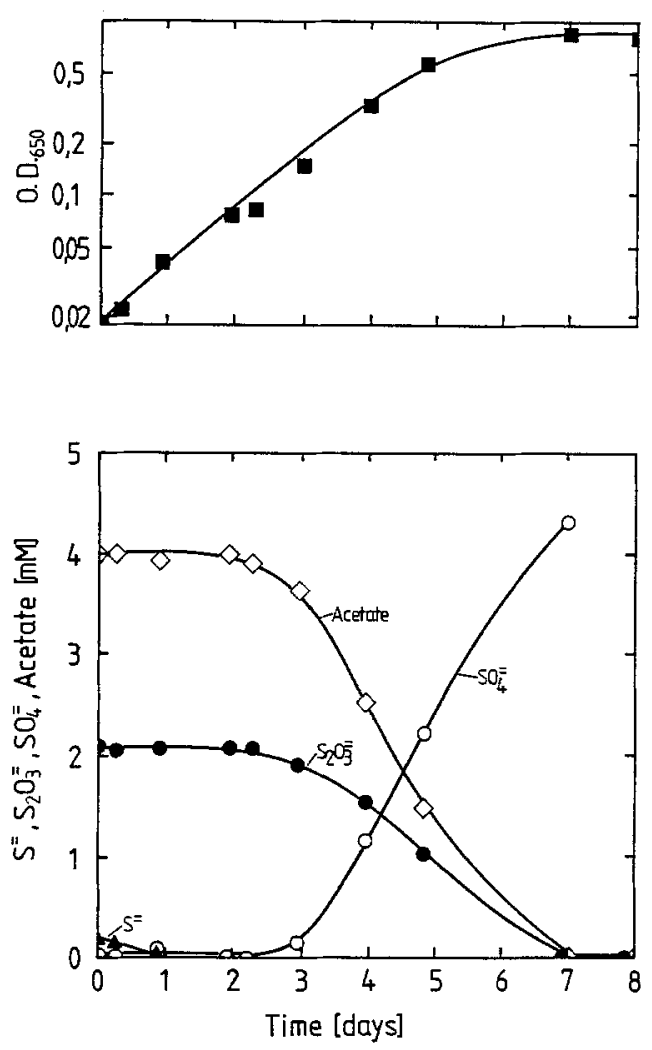

Fig. 5. Mixotrophic growth of strain BU 1 on thiosulfate plus acetate. Upper panel: Time course of optical density measured at $650 \mathrm{~nm}$. Lower panel: Time course of sulfide, thiosulfate, sulfate, and acetate concentrations

Because of the possession of gas vacuoles and the formation of typical net-like microcolonies the new bacterium has to be affiliated to the genus Pelodictyon. Based on the data given in Bergey's Manual (8th edition, 1974) and several other publications (Pfennig and Cohen-Bazire 1967; Gorlenko 1972), the properties of the new strain are compared to those of other Pelodictyon species (Table 1). So far, the only brown species described is $P$. phaeum, which differs considerably in morphology and ecophysiology from Pelodictyon strain BU 1. Cells of $P$. phaeum are short rods and often curved. Round or irregularly shaped microcolonies embedded in mucus may be formed which resemble those of the green-colored P. luteolum (Gorlenko 1972; Table 1). With respect to cell shape, occurence of ternary fission, gas vacuoles and the formation of three-dimensional nets, our new isolate closely resembles $P$. clathratiforme, Also, the guanine plus cytosine content of the DNA is close to that of P. clathratiforme. On the basis of these similarities the new strain BU 1 represents the brown counterpart to the green $P$. clathratiforme and is therefore considered as the new species $P$. phaeoclathratiforme.

In their preliminary characterization of a brown Pelodictyon strain, Abella and Montesinos (1985) mentioned the formation of gas vacuoles at dim light and low temperatures $\left(\leq 10^{\circ} \mathrm{C}\right)$. In our experiments, the formation of gas vacuoles strongly depended on the light intensity, but no significant differences were observed at various temperatures. These results contradict the assumption, that environmental control of buoancy would be unimportant in the genus Pelodictyon (Clark and Walsby 1978). 
Table 1. Properties of the new Pelodictyon species in comparison to most similar other species of the genus. n.d. $=$ not determined. $P$. clathratiforme in only partly purified culture

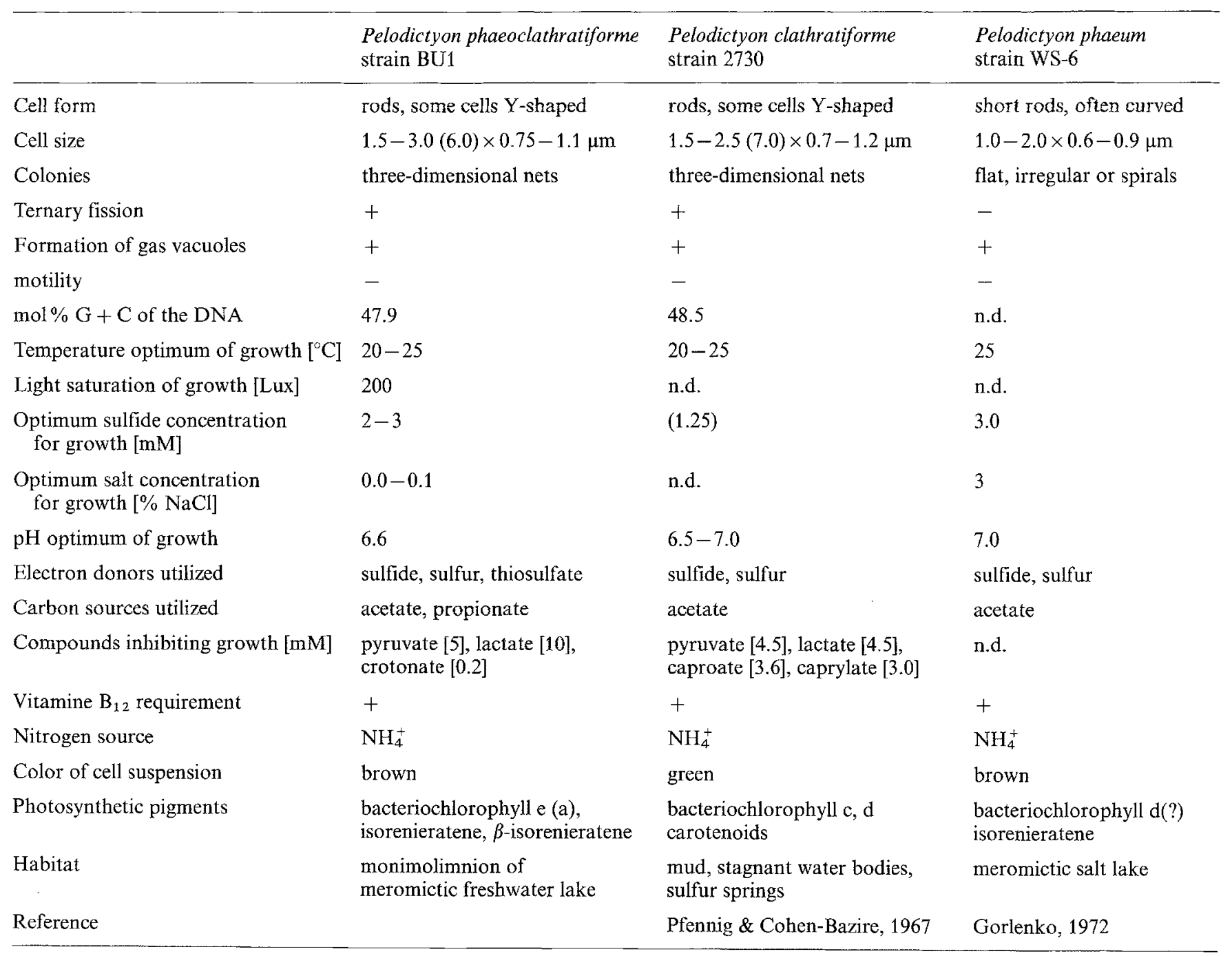

The small range of substrates photoassimilated by the Pelodictyon strain agrees with the limited physiological flexibility of the Chlorobiaceae. An outstanding feature of the new strain is its ability to use thiosulfate as the sole electron donor for growth. The stoichiometric conversion to sulfate was demonstrated (Figs 4 and 5). Up to now, no freshwater strain of the brown, gas-vacuolated members of the Chlorobiaceae with this property has been isolated. Brown Chlorobium strains using thiosulfate and requiring high salt concentrations for growth were isolated by Trüper and Genovese (1968) and Caumette (1984).

The possession of gas vacuoles and of isorenieratene $/ \beta$ isorenieratene as light-harvesting pigments enables $P$. phaeoclathratiforme to thrive at low light intensities in the anoxic water column of stratified lakes. The first pure culture of the new Pelodictyon species (Pfennig 1977) originated from the hypolimnion of the oligotrophic Plußsee (near Plön, Holstein, FRG). This bacterium was also observed in the hypolimnion of Mindelsee (near Radolfzell, Lake Constance region, FRG) where, similar to Buchensee, it was the dominating green sulfur bacterium.

Pelodictyon phaeoclathratiforme sp. nov. phae.o.clath.ra.ti.for'.me Gr.adj. phaeus brown; part.adj. clathratus latticed;
L.n. forma shape, form; M.L. neut.adj. phaeoclathratiforme brown lattice-like.

Individual cells are mostly rod-shaped, some become trapezoid at one end and develop into $Y$-shaped cells by ternary fission. Large three-dimensional netlike microcolonies may be formed. Cells $1.5-3.0$ (sometimes up to 6.0 ) $\mu \mathrm{m}$ long and $0.75-1.1 \mu \mathrm{m}$ wide. Cells are nonmotile and contain gas vacuoles in the central part of the cytoplasm. Color of dense cell suspensions dark brown. In transparent light, cultures exhibit a rose-red shine.

Contains bacteriochlorophyll $e$, isorenieratene and $\beta$ isorenieratene as major photosynthetic pigments, and small amounts of bacteriochlorophyll $a$.

Strictly anaerobic, obligately phototrophic. Growth occurs under anoxic and highly reducing conditions in the light. Electron donors used: Sulfide, sulfur, thiosulfate. Globules of sulfur are stored outside the cells during growth on sulfide. In the presence of electron donors and carbon dioxide, acetate and propionate are photoassimilated. No chemolithotrophic growth with sulfide as electron donor and nitrate as electron acceptor. Optimum sulfide concentration for growth $2-3 \mathrm{mM}$. Optimum $\mathrm{pH}$ 6.6. Optimum temperature $20-25^{\circ} \mathrm{C}$. Optimum light intensity $92 \mu \mathrm{E} \cdot \mathrm{m}^{-2}$ 
$\cdot \mathrm{s}^{-1}$. Vitamin $\mathrm{B}_{12}$ required for growth. Growth inhibited by pyruvate, lactate, crotonate. Habitat: Anoxic sulfide containing water of stratified holomictic or meromictic lakes.

DNA base ratio: $47.9 \mathrm{~mol} \%$ guanine plus cytosine.

Type strain: Strain BU 1. DSM No 5477.

Acknowledgements. We thank Dr. J. Floßdorf, Braunschweig, FRG, for the determination of the GC content.

\section{References}

Abella CA, Garcia-Gil J (1988) Diel migration as a mechanism for enrichment of natural populations of branching species of Pelodictyon. In: Olson JM, Ormerod JG, Amesz J, Stackebrandt E, Trüper HG (eds) Green Photosynthetic Bacteria. Plenum New York London, pp 269-285

Abella CA, Montesinos E (1985) Pelodictyon sp. strain 7502, the brown counterpart of Pelodictyon clathratiforme. Preliminary characterization. V. Intern. Symp. on Photosynthetic Prokaryotes. Grindelwald 1985, p 216

Bergey's Manual of Determinative Bacteriology, 8th edition (1974) Buchanan RE, Gibbons NE (eds). The Williams \& Wilkins Company, Baltimore

Caumette P (1984) Distribution and characterization of phototrophic bacteria isolated from the water of Bietri Bay (Ebrie Lagoon, Ivory Coast). Can J Microbiol 30:273-284

Clark AE, Walsby AE (1978) The development and vertical distribution of populations of gas-vacuolate bacteria in a eutrophic, monomictic lake. Arch Microbiol 118:229-233

Cline JD (1969) Spectrophotometric determination of hydrogen sulfide in natural waters. Limnol Oceanogr 14:454-458

Eichler B, Pfennig N (1986) Characterization of a new platelet forming purple sulfur bacterium Amoebobacter pedioformis sp. nov. Arch Microbiol 146:295-300

Floßdorf J (1983) A rapid method for the determination of the base composition of bacterial DNA. J Microbiol Meth 1:305-311

Gloe A, Pfennig N, Brockmann H, Trowitsch W (1975) A new bacteriochlorophyll from brown-colored Chlorobiaceae. Arch Microbiol 102:103-109

Gorlenko VM (1972) A new species of phototrophic brown sulfur bacteria, Pelodictyon phaeum nov. sp. Mikrobiologiya $41: 370-$ 371
Lauterborn R (1913) Zur Kenntnis einiger sapropelischer Schizomyceten. Allg Bot Z 7/8:97-100

Pfennig N (1968) Chlorobium phaeobacteroides nov. spec. and $C$. phaeovibrioides nov. sp., zwei neue Arten der grünen Schwefelbakterien. Arch Mikrobiol 63:224-226

Pfennig N (1977) Phototrophic green and purple bacteria: A comparative systematic survey. Ann Rev Microbiol 31:275-290

Pfennig N (1978) Rhodocyclus purpureus gen. nov. and spec. nov., a ring-shaped, vitamin $B_{12}$-requiring member of the family Rhodospirillaceae. Int J Syst Bacteriol 28:283-288

Pfennig N, Cohen-Bazire G (1967) Some properties of the green bacterium Pelodictyon clathratiforme. Arch Microbiol 59:226236

Pfennig N, Trüper HG (1971) New nomenclatural combinations in the phototrophic sulfur bacteria. Int J Syst Bacteriol 21:1114

Pfennig N, Trüper HG (1981) Isolation of members of the families Chromatiaceae and Chlorobiaceae. In: Starr HP, Stolp H, Trüper HG, Balows A, Schlegel HG (eds) The Prokaryotes. A handbook on habitats, isolation and identification of bacteria. Springer, Berlin Heidelberg New York, pp 179-289

Porter KG, Feig YS (1980) Use of DAPI for identifying and counting aquatic microflora. Limnol Oceanogr 25:943-948

Schink B, Pfennig N (1982) Fermentation of trihydroxybenzenes by Pelobacter acidigallici gen. nov. sp. nov., a new strictly anaerobic, non-sporeforming bacterium. Arch Microbiol 133:195201

Siefert E, Pfennig N (1984) Convenient method to prepare neutral sulfide solution for cultivation of phototrophic sulfur bacteria. Arch Microbiol 139:100-101

Trüper HG, Genovese S (1968) Characterization of photosynthetic sulfur bacteria causing red water in Lake Faro (Messina, Sicily). Limnol Oceanogr 13:225-232

Widdel F, Kohring GW, Mayer F (1983) Studies on dissimilatory sulfate reducing bacteria that decompose fatty acids. III. Characterization of the filamentous gliding Desulfonema limicola gen. nov. sp. nov., and Desulfonema magnum sp. nov. Arch Microbiol 134:286-294

Received June 7, 1989/Accepted June 21, 1989 